\title{
Challenging treatment of in-stent restenosis in a coronary bifurcation by implantation of a bioresorbable scaffold under optical coherence tomography guidance
}

\author{
Grzegorz Zuk ${ }^{1}$, Dariusz Ciecwierz ${ }^{1}$, Piotr Drewla ${ }^{1}$, Marcin Gruchala ${ }^{1}$, \\ Juan Luis Gutiérrez-Chico ${ }^{2,3}$, Milosz J. Jaguszewski ${ }^{1,3}$ \\ ${ }^{1}$ Interventional Cardiology, $1^{\text {st }}$ Department of Cardiology, University Clinical Center, Gdansk, Poland \\ ${ }^{2}$ Punta de Europa University Hospital, Algeciras (Cádiz), Spain \\ ${ }^{3}$ Institute of Cadiovascular Translational Research of the Atlantic (ICTRA), Berlin, Germany
}

This paper was guest edited by Prof. Marek Koziński

A 67-year-old male patient with stable angina, hypertension and hypercholesterolemia who underwent bare metal stent (BMS) implantation in the distal right coronary artery (RCA) (Azule $3 \times 9 \mathrm{~mm}$ ) and everolimus-eluting stent (EES) implantation in the first diagonal branch (D1) (Xience $2.25 \times 18 \mathrm{~mm})$ and in the proximal circumflex branch (LCx) (Xience $3 \times 28 \mathrm{~mm}$ ). One year subsequent to the precedure the patient was readmitted for relapse of the angina Canadian Cardiovascular Society scale II, exhibiting a positive exercise test. The coronary angiography showed a distal-edge in-stent restenosis (ISR) in the distal RCA, extending to the posterior descending artery (PDA), Medina 110 bifurcation (Fig. 1A). Optical coherence tomography (OCT) showed predominantly fibrolipidic restenotic tissue, with minimal lumen area (MLA) $1.95 \mathrm{~mm}^{2}$, minimal lumen diameter (MLD) $1.57 \mathrm{~mm}$, proximal reference vessel diameter (RVD) $3.1 \mathrm{~mm}$, distal RVD $2.75 \mathrm{~mm}$ and lesion length $21.2 \mathrm{~mm}$ (Fig. 1B, C).

Optical coherence tomography-guided implantation of a bioresorbable scaffold (BRS) to treat the bifurcation ISR was performed through a radial approach, using a 6 french guiding-catheter. Guidewires were placed in the PDA and in the posterolateral artery (PLA), in order to protect the side branch in case of an eventual occlusion. Predilation 1:1 with a non-compliant (NC) balloon $3.0 \times 18 \mathrm{~mm}(16 \mathrm{~atm})$ was performed until the balloon was completely expanded in angiography. A second OCT run verified fragmentation of restenotic tissue and sufficient luminal gain to ensure adequate scaffold expansion. A poly-lactide BRS (ABSORB $3 \times 28 \mathrm{~mm}$ ) was then slowly deployed at $12 \mathrm{~atm}$, holding pressure for $60 \mathrm{~s}$. Proximaloptimalization-technique with an NC-balloon $3.25 \times 15 \mathrm{~mm}(16 \mathrm{~atm})$ was then performed by placing the proximal edge of the distal marker of the balloon at the carina of the PDA-PLA bifurcation, with an optimal angiographic result (Fig. 1D). A final OCT pullback showed optimal apposition and expansion (MLA $5.3 \mathrm{~mm}^{2} / \mathrm{MLD} 2.6 \mathrm{~mm}$; Fig. 1E), structural integrity of the device and clear access to the PLA side branch through the scaffold struts (Fig. 1F). Three-month follow-up documented an optimal clinical and angiographical result (Suppl. Video 1).

Poly-lactide BRS are supposed to resorb completely [1-5], depending on the specific device and on patient/local conditions. The resorption restores vasomotion and eventually normal endothelial

Address for correspondence: Milosz J. Jaguszewski, MD, PhD, FESC, $1^{\text {st }}$ Department of Cardiology,

Medical University of Gdansk, ul. Dębinki 7, 80-210 Gdańsk, Poland, tel: +48 5834925 00, fax: +48 583461201 ,

e-mail: mjaguszewski@escardio.com.pl 


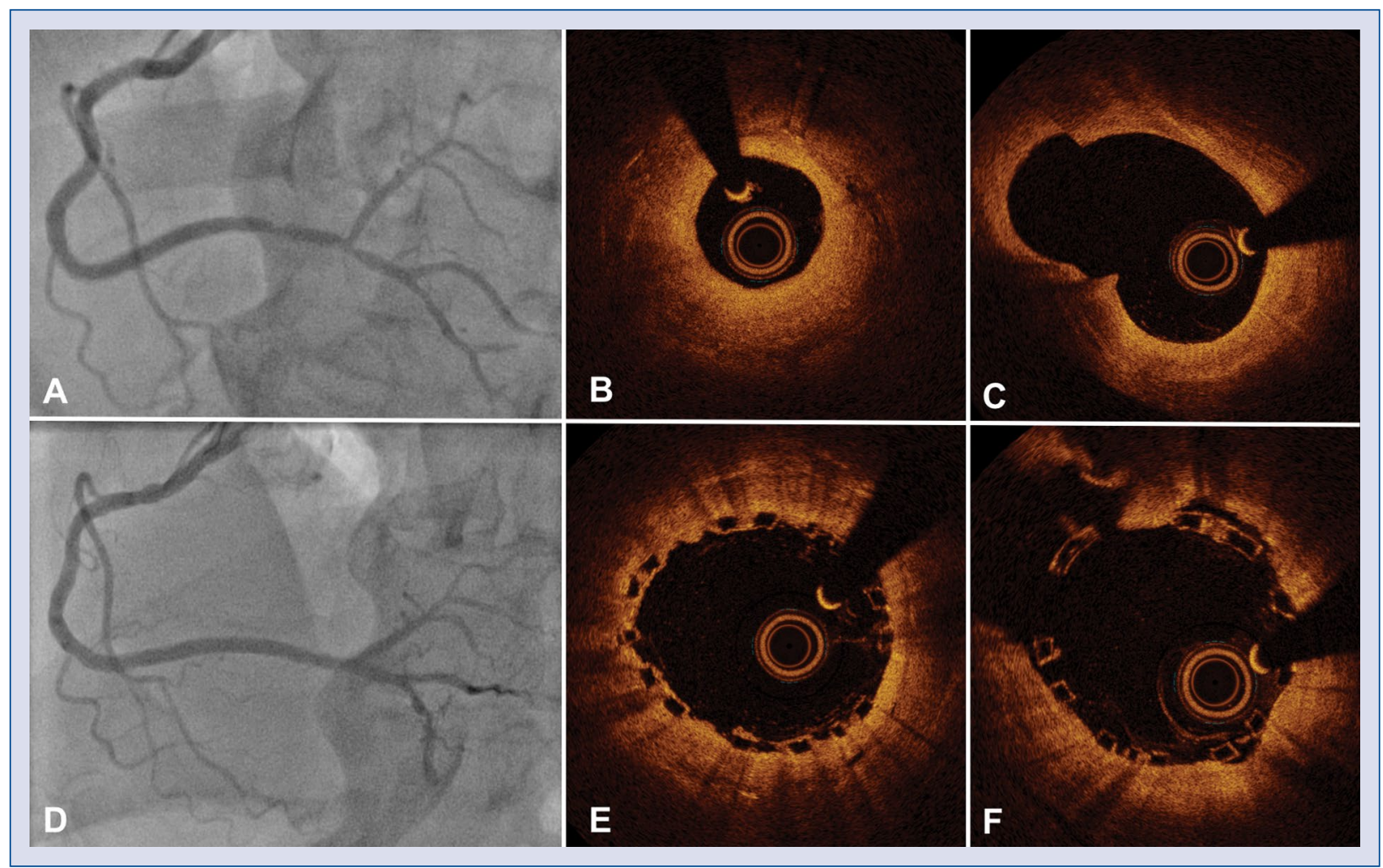

Figure 1. A, D. The coronary angiography shows a distal-edge in-stent restenosis in the distal right coronary artery, extending to the PDA, Medina 110 bifurcation; B, C. Optical coherence tomography (OCT) shows predominantly fibrolipidic restenotic tissue; D. An optimal angiographic result after proximal-optimalization-technique with a noncompliant-balloon $3.25 \times 15 \mathrm{~mm}$ (16 atm) performed by placing the proximal edge of the distal marker of the balloon at the carina of the PDA-PLA bifurcation; E, F. Optimal apposition, expansion and structural integrity of the device and clear access to the PLA side branch through the scaffold struts as assessed by OCT; PDA — posterior descending artery; PLA - posterolateral artery.

function [2, 6, 7]. Moreover, the disappearance of a permanent foreign body in the vessel wall is also intended to minimize inflammation and risk of device failure, i.e. very late BRS-thrombosis, neoatherosclerosis, restenosis and catch-up phenomenon. Nonetheless, the suitability of polylactide BRS for bifurcations is currently a matter of debate, with reported higher risks of side branch occlusion [8] and of scaffold rupture following some bifurcation techniques $[9,10]$. Some scientific reports however, focus on dedicating interventional techniques to minimize these risks $[10,11]$. ISR is also a challenging scenario for BRS, because the expansion of the scaffold is sensibly inferior than in on-label indications [12] and reported clinical outcomes are inconsistent to date [13, 14]. The current case reports the successful treatment of a lesion combining both bifurcation and ISR challenges, by implanting a BRS. OCT-guidance played an instrumental role in achieving an optimal result and it may be considered for all off-label indications of BRS devices.

\section{Conflict of interest: None declared}

\section{References}

1. Oberhauser JP, Hossainy S, Rapoza RJ. Design principles and performance of bioresorbable polymeric vascular scaffolds. EuroIntervention. 2009; 5 Suppl F: F15-F22, doi: 10.4244/EIJV5IFA3, indexed in Pubmed: 22100671.

2. Serruys PW, Ormiston JA, Onuma Y, et al. A bioabsorbable everolimus-eluting coronary stent system (ABSORB): 2-year outcomes and results from multiple imaging methods. Lancet. 2009; 373(9667): 897-910, doi: 10.1016/S0140-6736(09)60325-1, indexed in Pubmed: 19286089.

3. Onuma Y, Serruys PW, Perkins LEL, et al. Intracoronary optical coherence tomography and histology at 1 month and 2,3 , and 4 years after implantation of everolimus-eluting bioresorbable vascular scaffolds in a porcine coronary artery model: an attempt to decipher the human optical coherence tomography images 
in the ABSORB trial. Circulation. 2010; 122(22): 2288-2300, doi: 10.1161/CIRCULATIONAHA.109.921528, indexed in Pubmed: 20975003.

4. Verheye S, Ormiston JA, Stewart J, et al. A next-generation bioresorbable coronary scaffold system: from bench to first clinical evaluation: 6- and 12-month clinical and multimodality imaging results. JACC Cardiovasc Interv. 2014; 7(1): 89-99, doi: 10.1016/j.jcin.2013.07.007, indexed in Pubmed: 24139932.

5. Campos CM, Muramatsu T, Iqbal J, et al. Bioresorbable drugeluting magnesium-alloy scaffold for treatment of coronary artery disease. Int J Mol Sci. 2013; 14(12): 24492-24500, doi: 10.3390/ ijms141224492, indexed in Pubmed: 24351829.

6. Serruys PW, Onuma Y, Dudek D, et al. Evaluation of the second generation of a bioresorbable everolimus-eluting vascular scaffold for the treatment of de novo coronary artery stenosis: 12-month clinical and imaging outcomes. J Am Coll Cardiol. 2011; 58(15): 1578-1588, doi: 10.1016/j.jacc.2011.05.050, indexed in Pubmed: 21958884.

7. Serruys PW, Chevalier B, Dudek D, et al. A bioresorbable everolimus-eluting scaffold versus a metallic everolimus-eluting stent for ischaemic heart disease caused by de-novo native coronary artery lesions (ABSORB II): an interim 1-year analysis of clinical and procedural secondary outcomes from a randomised controlled trial. Lancet. 2015; 385(9962): 43-54, doi: 10.1016/ S0140-6736(14)61455-0, indexed in Pubmed: 25230593.

8. Muramatsu T, Onuma Y, García-García HM, et al. Incidence and short-term clinical outcomes of small side branch occlusion after implantation of an everolimus-eluting bioresorbable vascular scaffold: an interim report of 435 patients in the ABSORB-EXTEND single-arm trial in comparison with an everolimus-eluting metallic stent in the SPIRIT first and II trials. JACC Cardiovasc Interv. 2013; 6(3): 247-257, doi: 10.1016/j.jcin.2012.10.013, indexed in Pubmed: 23517836.
9. Ormiston JA, Webber B, Ubod B, et al. Absorb everolimus-eluting bioresorbable scaffolds in coronary bifurcations: a bench study of deployment, side branch dilatation and post-dilatation strategies. EuroIntervention. 2015; 10(10): 1169-1177, doi: 10.4244/ EIJY14M05_08, indexed in Pubmed: 24835848.

10. Ormiston JA, Webber B, Ubod B, et al. An independent bench comparison of two bioresorbable drug-eluting coronary scaffolds (Absorb and DESolve) with a durable metallic drugeluting stent (ML8/Xpedition). EuroIntervention. 2015; 11(1): 60-67, doi: 10.4244/EIJY15M02_03, indexed in Pubmed: 25680225

11. Derimay F, Souteyrand G, Motreff P, et al. Sequential proximal optimizing technique in provisional bifurcation stenting with everolimus-eluting bioresorbable vascular scaffold: fractal coronary bifurcation bench for comparative test between absorb and XIENCE xpedition. JACC Cardiovasc Interv. 2016; 9(13): 1397-1406, doi: 10.1016/j.jcin.2016.04.021, indexed in Pubmed: 27388830.

12. Rivero F, Bastante T, Cuesta J, et al. Treatment of in-stent restenosis with bioresorbable vascular scaffolds: optical coherence tomography insights. Can J Cardiol. 2015; 31(3): 255-259, doi: 10.1016/j.cjca.2014.11.017, indexed in Pubmed: 25660152.

13. Moscarella E, Ielasi A, Granata F, et al. Long-Term Clinical Outcomes After Bioresorbable Vascular Scaffold Implantation for the Treatment of Coronary In-Stent Restenosis: A Multicenter Italian Experience. Circ Cardiovasc Interv. 2016; 9(4): e003148, doi: 10.1161/CIRCINTERVENTIONS.115.003148, indexed in Pubmed: 27059683.

14. Jamshidi P, Nyffenegger T, Sabti $Z$, et al. A novel approach to treat in-stent restenosis: 6- and 12-month results using the everolimus-eluting bioresorbable vascular scaffold. EuroIntervention. 2016; 11(13): 1479-1486, doi: 10.4244/EIJV11I13A287, indexed in Pubmed: 27107313. 